\section{(6) OPEN ACCESS}

\title{
Pathogenic variants in the healthy elderly: unique ethical and practical challenges
}

\author{
Paul Lacaze, ${ }^{1}$ Joanne Ryan, ${ }^{1}$ Robyn Woods, ${ }^{1}$ Ingrid Winship, ${ }^{2,3}$ John McNeil ${ }^{1}$
}

\begin{abstract}
'Department of Epidemiology and Preventive Medicine, School of Public Health and Preventive Medicine, ASPREE - Monash University, Melbourne, Victoria, Australia

${ }^{2}$ Genetic Medicine and Family Cancer Clinic, Royal Melbourne Hospital, Melbourne, Victoria, Australia

${ }^{3}$ Department of Medicine, University of Melbourne, Royal Melbourne Hospital, Parkville, Victoria, Australia
\end{abstract}

\section{Correspondence to}

Dr Paul Lacaze, Department of Epidemiology and Preventive Medicine, School of Public Health and Preventive Medicine, Monash University, The Alfred Centre, 99 Commercial Road, Melbourne, VIC 3004, Australia; paul.lacaze@monash.edu

Received 28 September 2016 Revised 20 December 2016 Accepted 6 February 2017

Published Online First 24 March 2017

\section{ABSTRACT}

Genetic research into ageing, longevity and late-onset disease is becoming increasingly common. Yet, there is a paucity of knowledge related to clinical actionability and the return of pathogenic variants to otherwise healthy elderly individuals. Whether or not genetic research in the elderly should be managed differently from standard practices adapted for younger populations has not yet been defined. In this article, we provide an overview of ethical and practical challenges in preparing for a genetic study of over 14000 healthy Australians aged 70 years or older enrolled in the ASPirin in Reducing Events in the Elderly (ASPREE) Healthy Ageing Biobank. At the time of consent, all participants in this study were free of life-threatening illness, cardiovascular disease or cognitive impairment. ASPREE is thus a cohort of healthy elderly individuals with seemingly minimal burden of genetic disease recruited without ascertainment bias. The cohort presents a unique opportunity to address the penetrance of known pathogenic variants in a population without disease symptoms; however, it also raises a number of ethical concerns regarding the interpretation and disclosure of variants with known clinical actionability. Some of the challenges include (a) how to manage the interpretation, disclosure and actioning of pathogenic variants found in otherwise healthy elderly adults without disease symptoms, (b) whether or not to disclose findings for the benefit of family members rather than elderly consented donors themselves, (c) how to manage the return of genetic findings to the elderly individuals who are now in severe cognitive decline or terminal illness, (d) how to ensure quality of information and clinical service upon disclosure of results to this demographic and (e) how to prepare for the insurance implications of disclosing genetic information under Australian law. We discuss these and other dilemmas and propose a defensible plan of management.

Trial registration number ISRCTN83772183

\section{INTRODUCTION}

Research into chronic diseases of ageing, as well as the genetics of healthy ageing and longevity, means more elderly individuals are participating in genetic research. This is likely to increase in coming years as nations struggle with rapidly ageing populations and growing healthcare costs associated with chronic and degenerative diseases such as cancer, cardiovascular disease and dementia ${ }^{1-3}$ and seek improved understanding of how heritable factors may contribute to the risk of these diseases.

This article will discuss challenges encountered during the first-hand experience of preparing for a large genetic cohort study of Australia's ageing population (the ASPirin in Reducing Events in the Elderly (ASPREE) study ${ }^{4}$ ), involving targeted and whole genome sequencing (WGS) on thousands of healthy elderly research participants aged 70 years and older. Specifically, there is a paucity of knowledge related to clinical actionability and the return of secondary genetic findings to elderly individuals not displaying clinical symptoms of disease, resulting in unique ethical and practical challenges. This specific topic, to our knowledge, has not been the focus of any published report to date, despite a vast and growing literature on secondary genetic findings in general. ${ }^{5-12}$ Secondary genetic findings are usually discussed within the context of testing in a diagnostic setting, or within research studies and biobanks with adult donors not traditionally in the elderly demographic. Scarce attention has been given to the unique set of issues that arises when genetic research is conducted in elderly participants alone.

Whether or not the general course of action for delivery of actionable pathogenic variants needs to be different for elderly individuals (ie, here defined as 70 years or older), compared with the standard practice at younger ages, is unclear. However, it is likely to be an increasingly relevant question, as research in this area grows and genomic testing expands to the population. Evidence exists that older age may actually be positively associated with interest in disclosure, ${ }^{13}$ especially when the health benefit of family members is taken into account. Yet, well-defined mechanisms and processes for the review and disclosure of genetic findings in the elderly do not exist.

Our proposed plan for the management of actionable pathogenic variants in healthy elderly individuals is unique, given (a) participants were consented to be informed of findings if clear medical benefit exists to the individual or family members, but (b) we expect to find pathogenic variants in the genomes of healthy elderly individuals without major disease symptoms late into life. This presents the unconventional situation of disclosing genetic results in apparent cases of lifelong nonpenetrance for variants classified to be pathogenic and actionable. Disclosure of genetic findings in this cohort may therefore not always be for the sole purpose of clinical actioning in the individual (with apparent non-penetrance), but instead for the benefit of family members carrying the same often autosomal-dominant mutation who may subsequently be affected. This potentially raises ethical concerns related to the motivation of disclosure 
versus consent (table 1 provides definitions of some key genetic terms used in this article).

Here, we argue genetic information of potential medical significance to an individual's future health should be considered similarly for young or elderly individuals on ethical grounds. However, on practical grounds, we argue the interpretation of clinical utility and actionability of genetic findings in the elderly must be treated differently than in younger individuals. It is challenging to determine which genetic variants found in the genomes of otherwise healthy, elderly research participants can be considered of genuine medical benefit and clinical actionability to the individual. It is possible that genetic findings in elderly research participants may be of more practical value to younger blood relatives, where predictive testing would provide assessment and management of risks conferred by the sequence variant found. Therefore, clinical actionability in an elderly research cohort may shift in cascade onto younger family members, rather than remaining on the original elderly research participant who has provided consent. This reframes the traditional motivation for disclosure away from individual clinical actionability towards the interests of subsequent generations.

Table 1 Definitions of some of the key genetic terms used in this article.

\begin{tabular}{|c|c|}
\hline Term & Definition \\
\hline Whole genome sequencing & $\begin{array}{l}\text { Determining the DNA sequence of all genes in a } \\
\text { human genome simultaneously, as opposed to } \\
\text { targeting gene regions based on prior knowledge } \\
\text { or clinical context }\end{array}$ \\
\hline Pathogenic variant & $\begin{array}{l}\text { A change in DNA sequence that contributes } \\
\text { mechanistically to disease, but may not be } \\
\text { sufficient in isolation to cause disease }\end{array}$ \\
\hline Clinical actionability & $\begin{array}{l}\text { When identification of a genetic variant can be } \\
\text { followed with a defined and accepted course of } \\
\text { clinical action for an individual or their family }\end{array}$ \\
\hline Penetrance & $\begin{array}{l}\text { The number of individuals with a genetic variant } \\
\text { who develop an associated disease or trait as a } \\
\text { proportion of total individuals with the same } \\
\text { variant in the population }\end{array}$ \\
\hline Incomplete penetrance & $\begin{array}{l}\text { At the population level, when a given genetic } \\
\text { variant results in a disease or trait in some } \\
\text { individuals but not others; commonplace for most } \\
\text { polygenic disorders }\end{array}$ \\
\hline Non-penetrance & $\begin{array}{l}\text { Term used to describe when a genetic variant } \\
\text { does not result in its associated disease or trait in } \\
\text { a given individual }\end{array}$ \\
\hline Polygenicity & $\begin{array}{l}\text { When hundreds or even thousands of genetic } \\
\text { variants contribute to disease risk simultaneously, } \\
\text { often with low individual effect size and in } \\
\text { combination with environmental factors }\end{array}$ \\
\hline $\begin{array}{l}\text { Secondary or additional } \\
\text { genetic findings }\end{array}$ & $\begin{array}{l}\text { Known pathogenic DNA variants that may not be } \\
\text { the primary reason for genetic analysis but are } \\
\text { found during research or diagnostics. Can be } \\
\text { followed up with established courses of clinical } \\
\text { action and are often, but not necessarily, highly } \\
\text { penetrant }\end{array}$ \\
\hline Incidental genetic findings & $\begin{array}{l}\text { Genetic results with clinical actionability found } \\
\text { incidentally (not knowingly) within the scope of } \\
\text { research or clinical investigation }\end{array}$ \\
\hline $\begin{array}{l}\text { Autosomal dominant } \\
\text { inheritance }\end{array}$ & $\begin{array}{l}\text { When only one mutated copy of the genetic } \\
\text { variant, inherited from only one parent on a } \\
\text { non-sex (autosomal) chromosome, is sufficient to } \\
\text { cause disease; a parent with an autosomal } \\
\text { dominant condition has a } 50 \% \text { chance of having a } \\
\text { child with the condition }\end{array}$ \\
\hline
\end{tabular}

\section{CASE STUDY: THE ASPREE STUDY OF HEALTHY AGEING}

ASPREE is an international clinical trial to determine if daily low-dose aspirin can prolong disability-free survival when given to healthy older individuals. ${ }^{4}$ This randomised, double-blind, placebo-controlled trial for the primary prevention of cardiovascular disease, dementia, depression and some cancers is being undertaken in 19000 participants in Australia and the USA. There are 16703 participants from Australia, all aged 70 years or older at the time of study enrolment, with many individuals over 80 years. Throughout the course of the ASPREE study (average follow-up period of 5 years), each participant's health is monitored carefully with all adverse events recorded and study endpoints clinically adjudicated. ASPREE participants were in good health at the time of enrolment with no life-threatening illness, cardiovascular disease or cognitive impairment, which were all assessed at baseline. Thus, it can be considered as a healthy ageing cohort.

The ASPREE Healthy Ageing Biobank has collected biospecimens on more than 14000 ASPREE study participants, including consent for genetic research, as discussed further below. WGS has now commenced and will be performed on the oldest, healthiest members of the cohort. Further targeted gene sequencing analysis will be expanded to all ASPREE Biobank samples using a 'super-panel' approach to cover a broad range of clinically relevant genes and known disease-associated variants at deep sequencing depth. The purpose will be to assess the rate of known pathogenic variants across clinically relevant genes in a healthy elderly population at scale for the first time. Genetic data from these projects will be integrated back into ASPREE and used to aid epidemiological research plus act as a reference resource for the clinical genetics community in assigning pathogenicity and studying gene penetrance in a well-controlled healthy cohort sample.

In ASPREE, secondary genetic findings of actionable or clinical significance are not expected to be common because of the advanced age and healthy phenotype of the cohort. Nonetheless, based on recent genetic studies in ostensibly healthy adults, ${ }^{11} 14 \quad 15$ actionable pathogenic variants are expected to be found at a rate of around $1.0 \%-3.5 \%$ in the cohort. Consent for participation in the ASPREE Biobank included the possibility of returning actionable genetic findings of medical benefit to the individual or their family, should they be discovered. An ethically defensible plan on the review and return of secondary genetic findings has therefore been developed. During the process of obtaining ethics approval and beginning the study, the question arose whether to approach secondary findings differently from those approaches used in younger cohorts.

\section{RETURN OF GENETIC RESULTS IN THE ELDERLY ASPREE POPULATION}

Our default ethical position is that the right to be informed of clinically significant and actionable genetic information should be the same for an adult of any age, meaning there is no ethical argument to withhold actionable genetic findings based on age alone. However, we question the medical benefit and clinical value of returning genetic findings to some elderly individuals, particularly in cases where clinical intervention is unrealistic or unnecessary. These would need to be assessed on a case-by-case basis, but could include cases of unrelated terminal illness or severe cognitive decline, or contrastingly in cases of lifelong non-penetrance to the actionable genetic variant where an individual remains healthy. 
In clear cases of non-penetrance characterised by an absence of any family history or disease symptoms late into life, the obligation to disclose based on clinical actionability comes into question. If health intervention for the consenting individual alone is the only driver behind return of genetic findings, we argue it may not always be appropriate to disclose genetic findings to elderly participants in this context. However, if the potential clinical benefit and actionability of these findings to family members are taken into account, the rationale changes. Variants may not be penetrant in the elderly study participant, but may infer significant risk in offspring, and therefore prompt clinical intervention in subsequent generations.

The ASPREE Healthy Ageing Biobank Participant Information and Consent Form (PICF) states:

\begin{abstract}
If our research uncovers any significant information specific to your health, our ASPREE Biospecimen Governance Committee may decide to authorise someone to contact you and offer you access to this information. You may decline the information. If you wish to be given this information a qualified person will explain it to you. You should also consider whether this information should be made known to your family members. Sharing these findings could help avoid similar medical problems in your family.
\end{abstract}

The ASPREE study was therefore consented to leave open the possibility of returning medically significant genetic results to research participants and their families. The PICF was intended to cover all kinds of medical research, and was written years before the prospect of whole genome sequencing on thousands of individuals was thought feasible.

Nonetheless, in the process of applying for ethics approval and considering the possible implications of returning medically actionable genetic findings, we encountered a number of concerns regarding the ethical and practical challenges conducting this study. These concerns included (1) the potential anxiety, stress and worry caused to elderly research participants and their families upon receipt of genetic information they may not understand, (2) the possible impact on study participation burden given to individuals volunteered to participate specifically in a trial for aspirin, (3) the required disclosure of adverse genetic findings to travel and life insurance agencies under Australian law, (4) that some individuals might not wish to receive genetic results, despite previously giving informed consent, (5) the uncertainty around the genuine clinical benefit and actionability of returning results to elderly healthy individuals and (6) the obligation to return the findings to the offspring of individuals who had died or were cognitively impaired. A decision tree has been developed based on our experience in preparing for the return of actionable genetic findings in the ASPREE study (figure 1).

\section{CLINICAL UTILITY OF PATHOGENIC VARIANTS FOUND IN THE HEALTHY ELDERLY}

A current challenge to the field of human genetics is assigning pathogenicity and actionability to genetic variants. ${ }^{16}{ }^{17}$ This problem is compounded when found in otherwise healthy adults. In 2013, the American College of Medical Genetics (ACMG) released a list of 56 'actionable' genes, whereby pathogenic variants within are considered clinically actionable and worthy of reporting back to patients and research participants on ethical grounds (table 2). ${ }^{18}$ These are intended to represent examples where clinical action and intervention lead to a clear health benefit. In some cases, the clinical follow-up might include increased screening and surveillance, predictive testing of family members, drug prescriptions, or in some cases surgery.

The ACMG list has been adapted for the ASPREE study to help identify candidate genes for clinical review where disclosure or follow-up may be considered. The frequency and penetrance of these mutations within an elderly population have not been systematically measured; therefore, it is unclear how frequently they will be found in ASPREE. However, we have listed all ACMG diseases in order of expected frequency and considered each hypothetical course of clinical action if a mutation was found within a healthy $>70$-year-old individual. This information is summarised in table 2, which also includes disease incidence estimates according to the Online Mendelian Inheritance in Man (OMIM) compendium of human genes and genetic disease phenotypes. ${ }^{19}$ The reported incidence can be used as a rough estimate of the frequency at which the mutation might exist in a healthy population.

On the basis of recent studies of other adult populations, ${ }^{11} 1415$ it is estimated that between 200 and 500 candidate 'actionable' pathogenic mutations might be identified in a cohort the size of ASPREE. These will all need to be curated, interpreted and reviewed alongside patients' clinical records and family history before decisions regarding disclosure and actionability are made. A classification system and curation schedule for distinguishing benign versus actionable variants is being developed based on ClinVar guidelines. ${ }^{20}$

Most of the disorders included on the ACMG list are early-onset and autosomal-dominant inheritance, meaning it is unlikely that genuine cases of these diseases could exist in ASPREE participants aged 70 years or older. Any mutations in these early-onset disease genes found in ASPREE participants would therefore likely represent an example of lifelong nonpenetrance. Nonetheless, these findings will still need to be reviewed and interpreted within the context of family history and clinical features available to ASPREE.

A recent study of individuals carrying pathogenic variants in the Framingham Heart Study and African-American Jackson Heart Study, who did not have disease, found that these individuals were more likely to exhibit clinical features of the corresponding diseases than those without pathogenic variants. ${ }^{15}$ This suggests the presence of disease features or intermediate phenotypes in carriers of pathogenic variants, only discoverable through systematic phenotyping and mining of clinical data records. The most appropriate clinical action following discovery of this category of variants will be the predictive testing of first-degree relatives (50:50 familial risk). The same mutations can be passed onto future generations and may cause disease in offspring, presenting genuine opportunities for clinical action and preventative medical benefit.

Some conditions on the ACMG list have later onset-potentially beyond 70 years-for example, hereditary breast and ovarian cancer, Lynch syndrome, heritable cardiomyopathy or attenuated familial adenomatous polyposis. These diseases may still be actionable in some cases if found in elderly research participants aged 70 years or older, plus also in offspring. However, even for these diseases, we argue that the appropriate clinical action after finding a mutation in an elderly individual would likely be different from finding the same mutation in a younger adult, whereby intervention, screening or surgery may be more appropriate or feasible in the case of a younger adult. Each finding in this category of late-onset must therefore be interpreted on a case-by-case basis and within the context of clinical phenotype and family history, particularly to identify cases of genuine actionability versus those of non-penetrance. 
Figure 1 Decision tree for disclosure of actionable variants found during research involving ASPREE Biobank samples.

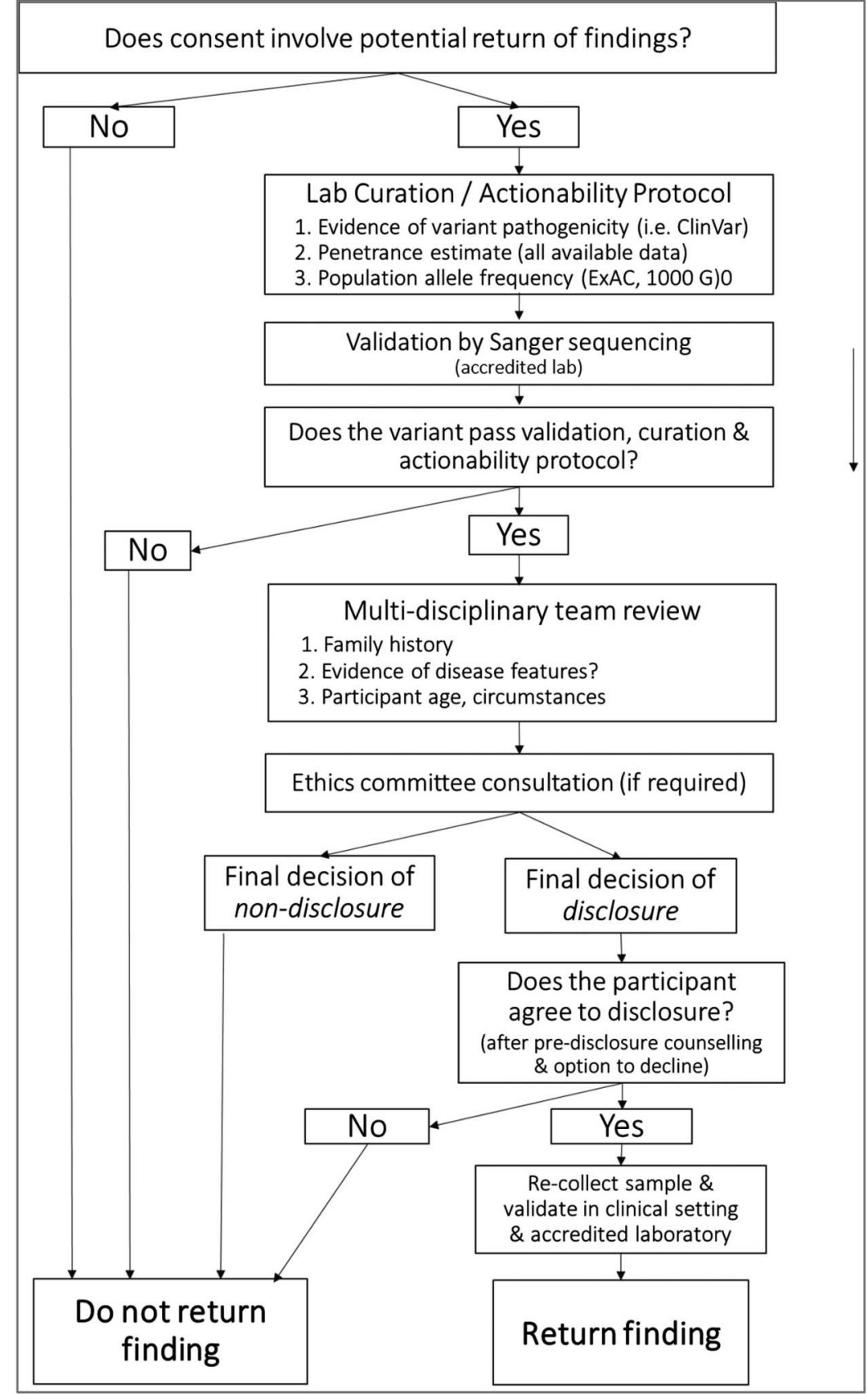

\section{THE ONGOING DEBATE AROUND DISCLOSURE VERSUS NON-DISCLOSURE OF GENETIC FINDINGS}

Genetic research involving healthy individuals is likely to raise different issues compared with genetic testing in a diagnostic or clinical setting. Research participants may prefer to provide DNA samples altruistically without an expectation of receiving results, and may not be prepared to address the familial or other implications of receiving secondary genetic findings, despite providing informed consent. Further, genetic findings from research can often be more difficult to interpret and action than results of clinical genetic testing because a specific diagnostic investigation is not performed with clinical details and family history routinely recorded. ${ }^{17}$ Incomplete penetrance in the population and polygenicity further complicate the interpretation of genetic findings from healthy research donors, especially the elderly.
There is still currently a lack of accepted protocols for the management and return of secondary genetic findings, despite some recent efforts to standardise these approaches. ${ }^{16} \quad 21 \mathrm{~A}$ number of protocols have been implemented by major genetic cohort studies $^{12}$ and biobanks; however, as shown in table 3, the policies vary quite considerably, and are not always publicly disclosed. A survey of 85 biobank practices, for example, found that only about half of the biobanks surveyed addressed the issue in publicly available documents. ${ }^{22}$ Without clear guidance, the final decision is ultimately left to each individual research group and ethics committee (IRB). ${ }^{6}$ Often, the decision is made not to return any findings for practical rather than ethical reasons (discussed below). Some initiatives ${ }^{23} 24$ have stated publicly that their policies and reportable gene lists will likely change over time as our understanding and knowledge improve. 
Table 2 ACMG actionable genes and possible courses of clinical action in the elderly

\begin{tabular}{|c|c|c|c|c|c|c|}
\hline Disease & Gene(s) & $\begin{array}{l}\text { Approximate } \\
\text { age of onset } \\
\text { (years) }\end{array}$ & $\begin{array}{l}\text { Incidence } \\
\text { (estimate) }\end{array}$ & $\begin{array}{l}\text { Clinical action (for child or } \\
\text { younger adult) }\end{array}$ & $\begin{array}{l}\text { Likely clinical action (for } \\
\text { elderly) }\end{array}$ & Implication for family \\
\hline $\begin{array}{l}\text { Hereditary breast and } \\
\text { ovarian cancer }\end{array}$ & $\begin{array}{l}\text { BRCA1, BRCA2, } \\
\text { PALB, ATM }\end{array}$ & $30-80$ & $1: 800$ & $\begin{array}{l}\text { Surgery, chemoprevention, } \\
\text { screening }\end{array}$ & $\begin{array}{l}\text { Annual mammography, } \\
\text { MRI; possible bilateral } \\
\text { salpingooophorectomy or } \\
\text { prophylactic mastectomy }\end{array}$ & $\begin{array}{l}\text { Predictive test for } \\
\text { first-degree relative } \\
\text { (50:50 risk) }\end{array}$ \\
\hline $\begin{array}{l}\text { Lynch syndrome-hereditary } \\
\text { non-polyposis colorectal } \\
\text { cancer }\end{array}$ & $\begin{array}{l}\text { MLH1, MSH2, } \\
\text { MSH6, PMS2 }\end{array}$ & 35 & $1: 800$ & $\begin{array}{l}\text { Primary prevention } \\
\text { (Nonsteroidal anti- } \\
\text { inflammatory drugs), } \\
\text { screening, early colonoscopy }\end{array}$ & $\begin{array}{l}\text { Colonoscopy, gynae } \\
\text { surveillance }\end{array}$ & $\begin{array}{l}\text { Predictive test for } \\
\text { first-degree relative } \\
(50: 50 \text { risk) }\end{array}$ \\
\hline $\begin{array}{l}\text { Romano-Ward, Long QT } \\
\text { syndrome (LQTS) types 1, } 2 \\
\text { and 3, Brugada syndrome } \\
\text { (cardiac) }\end{array}$ & $\begin{array}{l}\text { KCNQ1, } \\
\text { KCNH2, SCN5A }\end{array}$ & $\begin{array}{l}<18 \text { for LQTS; } \\
\text { infant to }>80 \text { for } \\
\text { Brugada }\end{array}$ & $1: 8000$ & Antiarrhythmic drugs & $\begin{array}{l}\text { Exercise test, flecainide } \\
\text { challenge }\end{array}$ & $\begin{array}{l}\text { Predictive test for } \\
\text { first-degree relative } \\
\text { (50:50 risk) }\end{array}$ \\
\hline $\begin{array}{l}\text { Familial } \\
\text { hypercholesterolaemia }\end{array}$ & $\begin{array}{l}\text { LDLR, APOB, } \\
\text { PCSK9 }\end{array}$ & $\begin{array}{l}\text { Mid-20s to late } \\
\text { adulthood }\end{array}$ & $1: 1000$ & Diet/lifestyle changes, statins & Statins & $\begin{array}{l}\text { Predictive test for } \\
\text { first-degree relative } \\
\text { (50:50 risk) }\end{array}$ \\
\hline Dilated cardiomyopathy & $\begin{array}{l}\text { TPM1, MYL3, } \\
\text { ACTC1, } \\
\text { PRKAG2, GLA, } \\
\text { MYL2, LMNA }\end{array}$ & Highly variable & $1: 2500$ & $\begin{array}{l}\text { Pharmacological, surgical, } \\
\text { pacemakers, implantable } \\
\text { defibrillators }\end{array}$ & Echocardiogram & $\begin{array}{l}\text { Predictive test for } \\
\text { first-degree relative } \\
(50: 50 \text { risk) }\end{array}$ \\
\hline $\begin{array}{l}\text { Marfan syndrome, } \\
\text { Loeys-Dietz syndrome, } \\
\text { familial thoracic aortic } \\
\text { Aneurysms and Dissections }\end{array}$ & $\begin{array}{l}\text { FBN1, TGFBR1, } \\
\text { TGFBR2, } \\
\text { SMAD3, } \\
\text { ACTA2, MYLK, } \\
\text { MYH11 }\end{array}$ & Highly variable & $1: 10000$ & $\begin{array}{l}\text { Surgery, chemoprevention, } \\
\text { screening }\end{array}$ & Echocardiogram & $\begin{array}{l}\text { Predictive test for } \\
\text { first-degree relative } \\
\text { (50:50 risk) }\end{array}$ \\
\hline retinoblastoma & RB1 & $<5$ & $1: 30000$ & $\begin{array}{l}\text { Ophthalmology, paediatric } \\
\text { oncology, pathology and } \\
\text { radiation oncology }\end{array}$ & Minimal—possibly eye exam & $\begin{array}{l}\text { Predictive test for } \\
\text { first-degree relative } \\
\text { (50:50 risk) }\end{array}$ \\
\hline $\begin{array}{l}\text { Hypertrophic } \\
\text { cardiomyopathy }\end{array}$ & $\begin{array}{l}\text { MYBPC3, } \\
\text { MYH7, TNNT2, } \\
\text { TNNI3 }\end{array}$ & $\begin{array}{l}\text { Adolescence to } \\
70+\end{array}$ & $<1: 50000$ & $\begin{array}{l}\text { Pharmacological, surgical, } \\
\text { pacemakers, implantable } \\
\text { defibrillators }\end{array}$ & Echocardiogram & $\begin{array}{l}\text { Predictive test for } \\
\text { first-degree relative } \\
\text { (50:50 risk) }\end{array}$ \\
\hline $\begin{array}{l}\text { Li-Fraumeni syndrome } \\
\text { (heritable cancer) }\end{array}$ & $\begin{array}{l}\text { TP53 (and } \\
\text { CHEK2) }\end{array}$ & $\begin{array}{l}\text { Children and } \\
\text { young adults, } \\
\text { before } 45\end{array}$ & $<1: 50000$ & $\begin{array}{l}\text { Standard cancer treatment, } \\
\text { avoiding radiation therapy }\end{array}$ & Avoid irradiation, surveillance & $\begin{array}{l}\text { Predictive test for first- } \\
\text { degree relative ( } 50: 50 \\
\text { risk) }\end{array}$ \\
\hline $\begin{array}{l}\text { Peutz-Jeghers syndrome } \\
\text { (polyps) }\end{array}$ & STK11 & Young adulthood & $<1: 50000$ & $\begin{array}{l}\text { Endoscopic surveillance with } \\
\text { polypectomy, family testing }\end{array}$ & Endoscopy surveillance & $\begin{array}{l}\text { Predictive test for } \\
\text { first-degree relative } \\
(50: 50 \text { risk) }\end{array}$ \\
\hline $\begin{array}{l}\text { Familial adenomatous } \\
\text { polyposis of the colon (APC, } \\
\text { Gardner syndrome) }\end{array}$ & $\begin{array}{l}\text { APC (and } \\
\text { MUTYH) }\end{array}$ & 20 & $<1: 100000$ & Colectomy & Colonoscopy & $\begin{array}{l}\text { Predictive test for } \\
\text { first-degree relative } \\
\text { (50:50 risk) }\end{array}$ \\
\hline $\begin{array}{l}\text { Tuberous sclerosis complex } \\
\text { (TSC) }\end{array}$ & $\mathrm{TSC} 1, \mathrm{TSC} 2$ & Childhood-30 & $1: 100000$ & $\begin{array}{l}\text { Mechanistic target of } \\
\text { rapamycin (mTOR) inhibitors, } \\
\text { neurosurgery, antiepileptic } \\
\text { drugs }\end{array}$ & Renal scans & $\begin{array}{l}\text { Predictive test for } \\
\text { first-degree relative } \\
\text { (50:50 risk) }\end{array}$ \\
\hline Neurofibromatosis type 2 & NF2 & $18-24$ & $1: 100000$ & Surgical, MRI screens & MRI & $\begin{array}{l}\text { Predictive test for } \\
\text { first-degree relative } \\
\text { (50:50 risk) }\end{array}$ \\
\hline $\begin{array}{l}\text { Catecholaminergic } \\
\text { polymorphic ventricular } \\
\text { tachycardia }\end{array}$ & $\begin{array}{l}\text { RYR2 (and } \\
\text { CALM1) }\end{array}$ & $\begin{array}{l}7-12 ; \text { rare cases } \\
>30\end{array}$ & $1: 100000$ & Antiarrhythmic medication & Echocardiogram & $\begin{array}{l}\text { Predictive test for } \\
\text { first-degree relative } \\
\text { (50:50 risk) }\end{array}$ \\
\hline $\begin{array}{l}\text { Arrythmogenic right } \\
\text { ventricular dysplasia/ } \\
\text { cardiomyopathy }\end{array}$ & $\begin{array}{l}\text { PKP2, DSP, } \\
\text { DSC2, } \\
\text { TMEM43, DSG2 }\end{array}$ & $32-40$ & 1:100 000 & $\begin{array}{l}\text { Antiarrhythmic medication, } \\
\text { implantable } \\
\text { cardioverter-defibrillators }\end{array}$ & Echocardiogram, MRI & $\begin{array}{l}\text { Predictive test for } \\
\text { first-degree relative } \\
\text { (50:50 risk) }\end{array}$ \\
\hline $\begin{array}{l}\text { Malignant hyperthermia } \\
\text { susceptibility }\end{array}$ & $\begin{array}{l}\text { RYR1, } \\
\text { CACNA1S }\end{array}$ & $\begin{array}{l}\text { Only after } \\
\text { anaesthetic }\end{array}$ & $1: 100000$ & $\begin{array}{l}\text { Ventilation, dantrolene, } \\
\text { cooling }\end{array}$ & Anaesthetic advice & $\begin{array}{l}\text { Predictive test for } \\
\text { first-degree relative } \\
\text { (50:50 risk) }\end{array}$ \\
\hline Von Hippel Lindau syndrome & VHL & Young adulthood & $\begin{array}{l}1 \text { in } 36000 ; \\
\text { high } \\
\text { penetrance; so } \\
\text { estimate } \\
<1: 100000\end{array}$ & Screening & $\begin{array}{l}\text { Surveillance evidence based- } \\
\text { renal scans, plasma } \\
\text { metanephrine }\end{array}$ & $\begin{array}{l}\text { Predictive test for } \\
\text { first-degree relative } \\
\text { (50:50 risk) }\end{array}$ \\
\hline $\begin{array}{l}\text { Multiple endocrine } \\
\text { neoplasia type } 1 \text { (MEN1) }\end{array}$ & MEN1 & $20-25$ & $<1: 300000$ & $\begin{array}{l}\text { Parathyroidectomy, } \\
\text { biochemical screening }\end{array}$ & Surveillance & $\begin{array}{l}\text { Predictive test for } \\
\text { first-degree relative } \\
(50: 50 \text { risk) }\end{array}$ \\
\hline $\begin{array}{l}\text { Hereditary paraganglioma- } \\
\text { pheochromocytoma } \\
\text { syndrome }\end{array}$ & $\begin{array}{l}\text { SDHD, SDHAF2, } \\
\text { SDHC, SDHB }\end{array}$ & 30 & $<1: 300000$ & $\begin{array}{l}\text { Early surveillance, followed by } \\
\text { pharmacological adrenergic } \\
\text { receptor blockade and surgery }\end{array}$ & Surveillance & $\begin{array}{l}\text { Predictive test for } \\
\text { first-degree relative } \\
(50: 50 \text { risk) }\end{array}$ \\
\hline
\end{tabular}


Table 2 Continued

\begin{tabular}{|c|c|c|c|c|c|c|}
\hline Disease & Gene(s) & $\begin{array}{l}\text { Approximate } \\
\text { age of onset } \\
\text { (years) }\end{array}$ & $\begin{array}{l}\text { Incidence } \\
\text { (estimate) }\end{array}$ & $\begin{array}{l}\text { Clinical action (for child or } \\
\text { younger adult) }\end{array}$ & $\begin{array}{l}\text { Likely clinical action (for } \\
\text { elderly) }\end{array}$ & Implication for family \\
\hline $\begin{array}{l}\text { Multiple endocrine } \\
\text { neoplasia type } 2 \text { : }\end{array}$ & RET & $50-70$ & $<1: 350000$ & $\begin{array}{l}\text { Parathyroidectomy, } \\
\text { biochemical screening }\end{array}$ & Surgery_thyroidectomy & $\begin{array}{l}\text { Predictive test for } \\
\text { first-degree relative } \\
\text { ( } 50: 50 \text { risk); surgery- } \\
\text { thyroidectomy in } \\
\text { childhood-consider } \\
\text { grandchildren }\end{array}$ \\
\hline $\begin{array}{l}\text { Familial medullary thyroid } \\
\text { cancer }\end{array}$ & $\begin{array}{l}\text { RET (and } \\
\text { NTRK1) }\end{array}$ & $0-70$ & $<1: 350000$ & $\begin{array}{l}\text { Parathyroidectomy, } \\
\text { biochemical screening }\end{array}$ & Surgery-thyroidectomy & $\begin{array}{l}\text { Predictive test for } \\
\text { first-degree relative } \\
\text { (50:50 risk); surgery- } \\
\text { thyroidectomy in } \\
\text { childhood-consider } \\
\text { grandchildren }\end{array}$ \\
\hline $\begin{array}{l}\text { PTEN hamartoma tumour } \\
\text { syndrome }\end{array}$ & PTEN & $20-30$ & $<1: 400000$ & Screening & Imaging & $\begin{array}{l}\text { Predictive test for } \\
\text { first-degree relative } \\
\text { (50:50 risk) }\end{array}$ \\
\hline $\begin{array}{l}\text { Ehlers-Danlos syndrome-- } \\
\text { vascular type }\end{array}$ & COL3A1 & $30-40$ & $1: 500000$ & $\begin{array}{l}\text { Medical, surgical management } \\
\text { of pain }\end{array}$ & Clinical assessment & $\begin{array}{l}\text { Predictive test for } \\
\text { first-degree relative } \\
\text { (50:50 risk) }\end{array}$ \\
\hline
\end{tabular}

ACMG, American College of Medical Genetics.

Table 3 Varying disclosure policies for the return of secondary findings from a selection of major biobanks and genetic cohort studies

\begin{tabular}{|c|c|c|c|}
\hline $\begin{array}{l}\text { No return of } \\
\text { secondary } \\
\text { genetic findings }\end{array}$ & $\begin{array}{l}\text { Will return } \\
\text { actionable genetic } \\
\text { findings (with } \\
\text { opt-in consent) }\end{array}$ & $\begin{array}{l}\text { Undecided/ } \\
\text { ongoing } \\
\text { decision }\end{array}$ & $\begin{array}{l}\text { No publicly } \\
\text { disclosed } \\
\text { policy on } \\
\text { website* }\end{array}$ \\
\hline UK Biobank ${ }^{29}$ & Genomics England ${ }^{23}$ & eMERGE ${ }^{30}$ & $\begin{array}{l}\text { Icelandic } \\
\text { Biobank } \\
\text { (DeCode) }\end{array}$ \\
\hline $\begin{array}{l}\text { Million Veteran } \\
\text { Program } \\
31\end{array}$ & $\begin{array}{l}\text { ASPREE Healthy } \\
\text { Ageing Biobank }^{4}\end{array}$ & $\begin{array}{l}\text { US Precision } \\
\text { Medicine } \\
\text { Initiative }^{32}\end{array}$ & $\begin{array}{l}\text { BioMe } \\
\text { (Mount } \\
\text { Sinai) }\end{array}$ \\
\hline $\begin{array}{l}\text { NINDS, National } \\
\text { Institute of } \\
\text { Neurological } \\
\text { Disorders and } \\
\text { Stroke } \\
\text { Repository, }{ }^{33}\end{array}$ & Geisinger MyCode ${ }^{34}$ & $\begin{array}{l}\text { Kaiser } \\
\text { Permanente } \\
\text { Research Program } \\
\text { on Genes, } \\
\text { Environment, and } \\
\text { Health }^{35}\end{array}$ & Welldery \\
\hline $\begin{array}{l}\text { BioVU (Vanderbilt } \\
\text { University) })^{36}\end{array}$ & $\begin{array}{l}\text { Genomes2People } \\
\text { (G2P) MedSeq } \\
\text { Project }^{24}\end{array}$ & $\begin{array}{l}\text { Framingham } \\
\text { Heart Study }{ }^{37}\end{array}$ & \\
\hline $\begin{array}{l}\text { NUgene } \\
\text { (Northwestern } \\
\text { University) }\end{array}$ & & & \\
\hline
\end{tabular}

Some of the main reasons biobanks and research studies may elect not to return secondary genetic findings include: (a) the possibility of returning ambiguous or interpretive information to otherwise healthy individuals, (b) time and resources required in variant curation, interpretation and review by scientists and clinicians, (c) costs associated with validation by Sanger sequencing, (d) genetic counselling support required and (e) potential legal and insurance implications of returning genetic information to research participants. Furthermore, genetic research involving WGS measures thousands of genes simultaneously generating vast amounts of data on each individual, thereby increasing the propensity and rate at which secondary or incidental genetic findings may be found.
In addition, the classification and assignment of pathogenicity to actionable genetic variants is a complex and evolving process. ${ }^{17}$ To eliminate the possibility of finding actionable variants when using whole exome or WGS, many researchers 'blind' themselves to actionable gene regions during DNA sequence analysis. This means genes with known clinical actionability are never actually seen, relinquishing the researchers of ethical and practical responsibilities associated with the management of secondary or incidental genetic findings. Although this approach may be understandable for practical reasons, the decision 'not to look' is itself a moral choice and requires justification, particularly when it is a proactive effort to do so. Blinding known important regions of the genome also ultimately limits our ability to investigate the variable penetrance and actionability of clinically important genes in different research and patient contexts.

Whether the above factors need to be reassessed in a specific context for the elderly has not yet been considered thoroughly. With regard to policies on return of secondary genetic findings, it is worth noting no re-contact model can actually limit the capacity of research when it comes to follow-up, resampling, validation and longitudinal studies. Recently, the Resilience Project, an initiative to find rare individuals who have childhood-onset, disease-causing mutations but do not develop disease symptoms into adulthood, identified 13 rare candidates from a retrospective data mining analysis of over 500000 deidentified genomes. ${ }^{25}$ This finding provided evidence of rare protection against what were thought to be fully penetrant disease-causing mutations. However, ultimately any follow-up or validation studies of the resilience candidates were restricted by the consent models used by many of the contributing cohorts which prohibited any participant recontact.

\section{AUSTRALIAN NATIONAL GUIDELINES}

In Australia, the National Health and Medical Research Council (NHMRC) has guidelines to encourage review and possible reporting of secondary or incidental findings from genetic research on ethical grounds. The Australian National Statement on Ethical Conduct in Human Research (2007) section 3.5.1 states 
Where research may discover or generate information of potential importance to the future health of participants, or their blood relatives, researchers must prepare and follow an ethically defensible plan to disclose or withhold that information.

Although this guideline does not explicitly require Australian researchers to return genetic findings, it does encourage review and potential disclosure of genetic information which may influence the individual or direct family members. The final decision is ultimately left up to the research group and ethics committee. The NHMRC guideline applies to all clinical testing, familial genetics and research studies involving human participants, regardless of patient/participant age, demographic or informed consent status. This suggests all contexts and participant groups should be considered equally, which we will argue is not necessarily the case within some specific groups with unusual circumstances, including the elderly.

In Australia, individuals who participate in genetic research are obliged to disclose the results to their insurer if they are themselves informed of the results. The genetic results can then be used by insurers in calculating risk and issuing policies. Secondary findings from genetic research (in Australia) may therefore have implications when research participants seek rated insurance (ie, life, income protection or travel insurance) and thus pose a problem if so-called 'risk variants' are identified. This may be less of an issue in the elderly if traditional 'risk variants' have not inferred disease risk during that individual's life span, but is contingent on the insurer actually understanding the concept of incomplete penetrance in the population, and excluding these variants from risk calculations for that individual.

Insurers' risk models and policy decisions are likely to change over time, while remaining far from transparent or available to the public or researchers. This makes it difficult for researchers and ethics committees to make decisions on the return of genetic findings on ethical grounds when the exact insurance

Table 4 Ethical and practical considerations for the reporting of secondary findings from genetic research in the elderly for the ASPREE study

\begin{tabular}{|c|c|}
\hline Pros & Cons \\
\hline $\begin{array}{l}\text { Ethical responsibility - not ethically } \\
\text { defensible to withhold actionable } \\
\text { medical information, consistent with } \\
\text { ACMG and other guidelines }\end{array}$ & $\begin{array}{l}\text { Ethical dilemma-decisions required by } \\
\text { researchers on what to report, when } \\
\text { and how }\end{array}$ \\
\hline $\begin{array}{l}\text { Autonomy - respect, the 'right to } \\
\text { know', avoids paternalism, consistent } \\
\text { with ASPREE consent }\end{array}$ & $\begin{array}{l}\text { Anxiety-possible stress and confusion } \\
\text { for research participants, families and } \\
\text { researchers; family members were not } \\
\text { consented to receive findings }\end{array}$ \\
\hline $\begin{array}{l}\text { Individual health benefit-clinical } \\
\text { intervention could potentially prevent } \\
\text { disease in individuals and their } \\
\text { families }\end{array}$ & $\begin{array}{l}\text { Is there genuine health benefit?-to } \\
\text { those already severely ill, elderly or in } \\
\text { cognitive decline, in obvious cases of } \\
\text { incomplete penetrance }\end{array}$ \\
\hline $\begin{array}{l}\text { Health economics-earlier } \\
\text { interventions, increased screening, } \\
\text { overall cost savings; genetic } \\
\text { counselling supported by Australian } \\
\text { healthcare system }\end{array}$ & $\begin{array}{l}\text { Resource burden-variant curation, } \\
\text { interpretation, validation, clinical } \\
\text { review, genetic counselling, insurance } \\
\text { implications }\end{array}$ \\
\hline $\begin{array}{l}\text { Scientific - helps the study of } \\
\text { penetrance, pathogenicity and clinical } \\
\text { actionability in different contexts }\end{array}$ & $\begin{array}{l}\text { Ambiguity-variant pathogenicity, path } \\
\text { of clinical intervention can be } \\
\text { uncertain, dealing with incomplete } \\
\text { penetrance }\end{array}$ \\
\hline
\end{tabular}

implications of doing so are unknown or difficult to interpret. It is unclear how insurers should handle the situation of a known pathogenic variant found in an otherwise healthy elderly individual. One of the few known genetic research studies conducting WGS on elderly populations, the Wellderly Study, ${ }^{26}$ decided not to report any secondary findings back to participants due to the risk of returning false-positive results to a healthy elderly population and the lack of local genetic counsellor support required (personal communications).

It is reasonable to expect the underlying rate of pathogenic variants would be similar in an elderly population versus a younger population of comparable ethnicity. However, the clinical phenotype and penetrance of the variants may be significantly different in the older healthy cohort, given the longer confirmed absence of disease symptoms. This could challenge traditional definitions of clinical actionability for many pathogenic variants if/when found in healthy, elderly research donors. How this ambiguity is to be handled by researchers who discover variants during cohort sequencing studies is unclear.

\section{ETHICAL ARGUMENTS FOR AND AGAINST RETURNING GENETIC FINDINGS IN THE ELDERLY}

Like any challenging ethical question, the argument on whether or not to return secondary findings of genetic research to the elderly has both pros and cons. Some of these are particularly relevant to the elderly population, or need to be viewed differently based on age, clinical context or phenotype (table 4). The practical challenges centre around adequately resourcing the data quality and QC, variant calling, curation and interpretation process, clinical review of pathogenic results, communication and contact with the patient, resampling and validation by Sanger sequencing, final recommendation of action and genetic counselling. This is a significant undertaking when conducted at scale, anticipating between 200 and 500 actionable findings in APSREE plus cascade testing of family members. This represents a sizeable resource burden on both the Australian clinical services and research staff. These are not reasons the results should not be returned, but rather the realities of the decision to return findings. Indeed, these challenges will continue to mount as genomic testing becomes more widespread throughout the society in different contexts.

An argument can be made for withholding genetic findings in the case of elderly research participants in severe cognitive decline, terminal illness or deceased at time of variant discovery. In these cases, there may be no possibility of clinical actionability or medical benefit to the individual, yet still possible benefit to family members. Here, a decision will be required whether to inform family members of the result, despite the fact family members never consented to receive genetic information. Any decision of non-disclosure over-riding participant autonomy would need to be well articulated and justified.

If and when actionable findings from ASPREE are identified, the format and procedure for disclosure will be conducted within established services of the Australian healthcare system. Initially, ASPREE participants will be informed of genetic findings via a letter from a clinical geneticist, without disclosing the specific details of the finding. At that stage, the participant will have the opportunity to refuse any further information, or elect to proceed further (figure 1). An explanation of the concept of non-penetrance will be provided at this time. Upon electing to proceed further, recollection of a biospecimen will be required for further validation of the result, followed by delivery of confirmed results by clinical genetic services in line with standard 
practice of the Australian healthcare system. This will include pretest and post-test genetic counselling where required.

A research protocol is also being developed around the return of genetic findings from ASPREE to help track outcomes after receipt of genetic information. Recipients of genetic findings will be therefore offered the chance to participate in further research to help monitor the longitudinal consequences of returning genetic data to otherwise healthy elderly adults and their families.

\section{CONCLUSION: WHO IS ULTIMATELY RESPONSIBLE FOR DECIDING OUR ETHICAL COURSE OF ACTION?}

Ultimately, our study of genetics in the elderly will focus on asking the unusual research question of how frequently we might find pathogenic DNA variants previously thought to be disease-causing, in an otherwise healthy elderly population. Specifically, we aim to investigate the rate of non-penetrance for clinically actionable mutations in individuals who remain healthy to an advanced age.

We have questioned the return of genetic information to elderly research participants for the following reasons: (1) if the mutation in question were genuinely disease-causing in the individual, it would likely have manifested by the age of 70 , meaning there may be limited opportunity for clinical intervention, (2) participants in an elderly cohort are (predominantly) of postreproductive age, and carrier status is thus irrelevant (although as discussed above, could still be an important issue for their families), (3) there are insurance implications to consider for the elderly demographic under current Australian regulations, (4) participants are not necessarily expecting genetic results to be returned (as per informed consent) and thus may not be prepared for this and (5) the classification, reliability and actionability of some genetic variants is still in question, even in some cases for genes with known clinical actionability on the ACMG list. ${ }^{14} 15$

For these reasons, we argue that the ethical and practical model for the return of secondary genetic findings from research in an elderly cohort should be given different context than younger cohorts. Any disclosed findings must have genuine clinical benefit to the participant or their family which will need to be clearly defined and communicated. Genetic variants usually considered to be actionable or penetrant may not be in the healthy elderly, suggesting their classification as clinically actionable may need to be revised in light of clinical context, family history and/or phenotype.

The main motivation behind return of genetic findings in the ASPREE study may tend towards the health benefit of younger family members of elderly ASPREE participants, rather than the research participants themselves. This raises an ethical concern, given younger family members did not provide consent to receive such findings. It is of utmost importance for this reason that any disclosed findings have the potential to infer genuine medical benefit to family members involved and can be supported by a strong evidence base.

Our ethically defensible plan leaves a degree of flexibility for judgement, review and consensus decision-making on actionability for the reasons discussed in this article. There will inevitably be areas where judgement is required in this rapidly moving field. Decisions will require input from a multidisciplinary team of scientists, clinical geneticists, study managers, genetic counsellors and an independent ethics committee. Fortunately, Australian participants in ASPREE who receive secondary genetic findings will have access to government-supported clinical genetic services and genetic counselling as part of the
Australian healthcare system. This will also support cascade testing and genetic counselling for family members.

In closing, we anticipate finding a low frequency of genuinely pathogenic, actionable genetic mutations in the ASPREE cohort $\left(1.0 \%-3.5 \%\right.$ for European descent $\left.{ }^{15} 2728\right)$. Mutations will be reviewed by a genetics advisory board on a case-by-case basis, but not necessarily reported back to the participant unless clear medical benefit is derived for the participant or their offspring. The interpretation of genetic variants will be complicated as we anticipate finding pathogenic variants in otherwise healthy individuals who have reached an advanced age without disease symptoms (ie, non-penetrance). In other circumstances, penetrant mutations may be found, but not deemed clinically actionable due to the patient's circumstances of being elderly, in cognitive decline, severely ill or in the absence of any related disease symptoms. Findings may be returned to blood relatives in these circumstances.

The field of human genetics is changing rapidly, especially with regard to the interpretation of pathogenic mutations and what they mean to each individual. Studies of known pathogenic variants in ostensibly healthy adults and their families will therefore be instrumental in providing the much-needed clarity in our understanding of penetrance, pathogenicity and genetic determinism. If pathogenic variants found in otherwise healthy adults can be disclosed and followed up with detailed longitudinal phenotyping and family studies, it could shed light on mechanisms of penetrance and resilience against pathogenic mutations. However, doing this may not always be in the individual's best interest, or result in direct clinical action. This presents an unresolved dilemma which must be addressed by the genetics community. Clinically significant findings from large cohort sequencing studies cannot remain in the deidentified realm of research forever. Recontact and phenotypic follow-up will be essential if we are to advance our understanding of causative genetic variation in human health and disease.

\section{Twitter Follow Paul Lacaze @PaulLacaze}

Acknowledgements The principal funder of ASPREE is the US National Institutes of Health (a grant from the National Institute on Aging, grant number U01AG029824), with additional contributions from the NHMRC (grant numbers 334047, 1127060), Monash University and the Victorian Cancer Agency. Study medication is provided by Bayer HealthCare. The ASPREE Healthy Ageing Biobank has been funded by the Commonwealth Scientific and Industrial Research Organisation and the US National Cancer Institute. The authors thank Professor Bruce Holloway for his significant contributions to the ASPREE study and this manuscript.

Contributors PL wrote the manuscript and provided the intellectual conception of the article. RW and JM made substantial contributions to the conception and design of the work. JR and IW were critical in providing intellectual input and drafting and revising the article.

\section{Competing interests None declared.}

Ethics approval The Alfred Hospital Office of Ethics and Research Governance.

Provenance and peer review Commissioned; externally peer reviewed.

Open Access This is an Open Access article distributed in accordance with the Creative Commons Attribution Non Commercial (CC BY-NC 4.0) license, which permits others to distribute, remix, adapt, build upon this work non-commercially, and license their derivative works on different terms, provided the original work is properly cited and the use is non-commercial. See: http://creativecommons.org/ licenses/by-nc/4.0/

\section{REFERENCES}

1 Lewis FI, Torgerson PR. The current and future burden of late-onset dementia in the United Kingdom: Estimates and interventions. Alzheimers Dement 2017:13:38-44.

2 Annear MJ, Tierney LT, Vickers JC, et al. Counting the cost of dementia-related hospital admissions: a regional investigation. Australas J Ageing 2016;35:E32-5.

3 Abdin E, Subramaniam M, Achilla E, et al. The societal cost of dementia in Singapore: results from the WiSE study. J Alzheimers Dis 2016;51:439-49. 
4 Group Al. Study design of ASPirin in Reducing Events in the Elderly (ASPREE): a randomized, controlled trial. Contemp Clin Trials 2013;36:555-64.

5 Middleton A, Morley Kl, Bragin E, et al. Attitudes of nearly 7000 health professionals, genomic researchers and publics toward the return of incidental results from sequencing research. Eur J Hum Genet 2016;24:21-9.

6 Gliwa C, Yurkiewicz IR, Lehmann LS, et al. Institutional review board perspectives on obligations to disclose genetic incidental findings to research participants. Genet Med 2016;18:705-11.

7 Jelsig AM, Qvist N, Brusgaard K, et al. Research participants in NGS studies want to know about incidental findings. Eur J Hum Genet 2015;23:1423-6.

$8 \mathrm{Yu} \mathrm{JH}$, Harrell TM, Jamal SM, et al. Attitudes of genetics professionals toward the return of incidental results from exome and whole-genome sequencing. Am J Hum Genet 2014;95:77-84.

9 Wallace SE, Walker NM, Elliott J. Returning findings within longitudinal cohort studies: the 1958 birth cohort as an exemplar. Emerg Themes Epidemiol 2014:11:10.

10 Kleiderman E, Knoppers BM, Fernandez CV, et al. Returning incidental findings from genetic research to children: views of parents of children affected by rare diseases. J Med Ethics 2014;40:691-6.

11 Dorschner MO, Amendola LM, Turner EH, et al. Actionable, pathogenic incidental findings in 1,000 participants' exomes. Am J Hum Genet 2013:93:631-40.

12 Wolf SM, Crock BN, Van Ness B, et al. Managing incidental findings and research results in genomic research involving biobanks and archived data sets. Genet Med 2012;14:361-84

13 Allen NL, Karlson EW, Malspeis S, et al. Biobank participants' preferences for disclosure of genetic research results: perspectives from the OurGenes, OurHealth, OurCommunity project. Mayo Clin Proc 2014:89:738-46.

14 Song W, Gardner SA, Hovhannisyan H, et al. Exploring the landscape of pathogenic genetic variation in the ExAC population database: insights of relevance to variant classification. Genet Med 2016;18:850-4

15 Natarajan P, Gold NB, Bick AG, et al. Aggregate penetrance of genomic variants for actionable disorders in European and African Americans. Sci Trans/ Med 2016;8:364ra151

16 Jarvik GP, Amendola LM, Berg JS, et al. Return of genomic results to research participants: the floor, the ceiling, and the choices in between. Am J Hum Genet 2014:94:818-26.

17 MacArthur DG, Manolio TA, Dimmock DP, et al. Guidelines for investigating causality of sequence variants in human disease. Nature 2014;508:469-76.

18 Green RC, Berg JS, Grody WW, et al. ACMG recommendations for reporting of incidental findings in clinical exome and genome sequencing. Genet Med 2013:15:565-74

19 Amberger JS, Bocchini CA, Schiettecatte F, et al. OMIM.org: Online Mendelian Inheritance in Man (OMIM $®)$, an online catalog of human genes and genetic disorders. Nucleic Acids Res 2015;43:D789-98.

20 Landrum MJ, Lee JM, Benson $\mathrm{M}$, et al. ClinVar: public archive of interpretations of clinically relevant variants. Nucleic Acids Res 2016;44:D862-8.
21 Hehir-Kwa JY, Claustres M, Hastings RJ, et al. Towards a European consensus for reporting incidental findings during clinical NGS testing. Eur J Hum Genet 2015;23:1601-6.

22 Johnson G, Lawrenz F, Thao M. An empirical examination of the management of return of individual research results and incidental findings in genomic biobanks. Genet Med 2012:14:444-50.

23 Genomics England, What can participants find out? https:// http://www. genomicsengland.co.uk/taking-part/results/ (accessed Aug 2016).

24 Vassy JL, Lautenbach DM, McLaughlin HM, et al. The MedSeq Project: a randomized trial of integrating whole genome sequencing into clinical medicine. Trials 2014;15:85.

25 Chen R, Shi L, Hakenberg J, et al. Analysis of 589,306 genomes identifies individuals resilient to severe Mendelian childhood diseases. Nat Biotechno/ 2016:34:531-8.

26 Erikson GA, Bodian DL, Rueda $\mathrm{M}$, et al. Whole-genome sequencing of a healthy aging cohort. Cell 2016;165:1002-11.

27 Van Driest SL, Wells QS, Stallings S, et al. Association of arrhythmia-related genetic variants with phenotypes documented in electronic medical records. Jama 2016;315:47-57

28 Walsh R, Thomson KL, Ware JS, et al. Reassessment of Mendelian gene pathogenicity using 7,855 cardiomyopathy cases and 60,706 reference samples. Genet Med 2017;19:192-203.

29 UK Biobank Ethics and Governance Framework, version 3.0, October 2007. http:// www.ukbiobank.ac.uk/wp-content/uploads/2011/05/EGF20082.pdf? phpMyAdmin=trmKQIYdjinQIgJ\%2CfAzikMhEnx6.pdf (accessed Aug 2016).

30 Lemke AA, Wu JT, Waudby $C$, et al. Community engagement in biobanking: Experiences from the eMERGE Network. Genomics Soc Policy 2010;6:35-52.

31 Million Veteran Program (MVP, Office of Research \& Development, Participation Section. http://www.research.va.gov/MVP/veterans.cfm (accessed Aug 2016).

32 The Precision Medicine Initiative Cohort Program-Building a Research Foundation for 21st Century Medicine. 17 September 2015. https://www.nih.gov/sites/default/ files/research-training/initiatives/pmi/pmi-working-group-report-20150917-2.pdf

33 The National Institute for Neurological Disorders and Stroke (NINDS) Human Genetics Initiative: Cell Line and DNA Repository. Frequently Asked Questions, 31 August 2011. http://ccr.coriell.org/Sections/Collections/NINDS/InvestigatorFAQ.aspx? Pgld=150 (accessed 22 Feb 2012).

34 MyCode Community Health Initiative. RESEARCH CONSENT/AUTHORIZATION FORM. 02/22/2016. http://www.geisinger.org/for-researchers/ partnering-with-patients/includes/pdf/MyCode\%20Main\%20Consent\%20V29.pdf

35 Kaiser Permanente Research Program on Genes, Environment, and Health (RPGEH), FAQs. https://www.dor.kaiser.org/external/DORExternal/rpgeh/faq.aspx? ekmensel=194f64c3_47_69_btnlink\#7

36 Vanderbilt University Medical Center. Vanderbilt BioVU. FAQ. https://victr.vanderbilt. edu/pub/biovu/?sid=218 (accessed Aug 2016).

37 Levy D, Splansky GL, Strand NK, et al. Consent for genetic research in the Framingham Heart Study. Am J Med Genet A 2010;152A:1250-6.

38 NUgene Project-How to participate. https:// http://www.nugene.org/pages/ participate (accessed Aug 2016) 